\title{
Hubungan Perilaku Picky eater dengan Tingkat Kecukupan Zat Gizi dan Status Gizi Anak Usia Prasekolah Di Gayungsari
}

\section{Correlation of Picky Eater with Intake Adequacy and Nutritional Status in Preschool-Aged Children in Gayungsari}

\author{
Adhelia Niantiara Putri*, Lailatul Muniroh
}

\begin{abstract}
ABSTRAK
Latar belakang: Picky eater adalah perilaku memilih-milih makanan yang ditandai dengan terbatasnya jumlah pilihan makanan. Kejadian picky eater pada anak prasekolah berakibat kekurangan asupan jangka panjang, sehingga dapat mengganggu pertumbuhan anak.

Tujuan: Tujuan penelitian ini adalah menganalisis hubungan antara perilaku picky eater dengan tingkat kecukupan zat gizi dan status gizi pada anak usia prasekolah di KB-TK Al-Hikmah Surabaya.

Metode: Penelitian ini merupakan penelitian observasional analitik dengan desain cross-sectional. 45 subyek dengan usia 41-59 bulan berpartisipasi dalam penelitian ini. Metode simple random sampling digunakan untuk pengambilan sampel. Pengumpulan data meliputi pengukuran antropometri, pengisian Child Eating Behavior Quiessionare, dan tingkat kecukupan gizi menggunakan Semi-Quantitative Food Frequency Questionnaire. Seluruh data dianalisis menggunakan SPSS v25.0 dengan uji Spearman's Rho.

Hasil: Hasil menunjukkan $57,8 \%$ responden memiliki perilaku picky eater. $40 \%$ subyek berkecukupan energi lebih namun $95,6 \%$ tingkat kecukupan serat kurang. Terdapat 22,2\% subyek dengan status gizi kurang, $13,3 \%$ subyek dengan stunting, dan $20 \%$ subyek dengan wasting. Sebanyak $23,1 \%$ subyek dengan perilaku picky eater memiliki status gizi kurang. Hasil penelitian ini menunjukkan adanya hubungan antara tingkat kecukupan energi $(p=0,000, r=-0,717)$, karbohidrat $(p=0,000$, $r=-0,566)$, protein $(p=0,007, r=-0,396)$, dan lemak $(p=0.000, r=-0,599)$ dengan kejadian picky eater namun tidak berhubungan dengan tingkat kecukupan serat $(p=0,825)$, status gizi $B B / U(p=0,444), T B / U(p=0,366)$ dan $B B / T B(p=0,235)$.

Kesimpulan: Subyek yang berperilaku picky eater memiliki tingkat kecukupan zat gizi lebih rendah. Picky eater berhubungan tingkat kecukupan zat gizi. Responden dan subyek dengan perilaku ini sebaiknya memperbaiki kebiasaan makan dan memperbanyak konsumsi serat untuk mencegah kejadian gizi kurang.
\end{abstract}

Kata kunci: picky eater, prasekolah, status gizi

\section{ABSTRACT}

Background: Picky eater is unwillingness to eat unfamiliar food or try new food as well as strong food preference. Picky eater behaviour in preschool-aged children might cause an insufficient intake of food and lead to impaired growth.

Objectives: This study aimed to analyze the correlation between picky eater with adequacy level of intake and nutritional status among preschool children in KB-TK Al-Hikmah Surabaya.

Methods: This study was an analytic observational study with a cross-sectional design. 45 subjects aged 41-59 months participated in this study. Simple random sampling method was used to select the sample of this study. Data were collected by measuring height, weight, filling Child Eating Behaviour Questionnaire, and nutrient intake by filling Semi-Quantitative Food Frequency Questionnaire. All data were analyzed using Spearman's Rho test using SPSS v25.0.

Results: This study discovered that $57.6 \%$ of subjects had picky eater behaviour, $40 \%$ subject had high intake of energy but 95,6\% subject had low fibre intake, $22.2 \%$ subject were malnutrition, $20 \%$ subject were wasting, $13.3 \%$ subject were categorized as stunting. Around $23.1 \%$ subject with picky eater behaviour had malnutrition. Energy intake level $(p=0.000$, $r=0.717)$, carbohydrate $(p=0.000, r=0.566)$, protein $(p=0.007, r=0.396)$, dan fat $(p=0.000, r=0.599)$ were correlated to picky eater behaviour. Subjects with picky eater tend to have lower intake level compared to non-picky eater subjects. All subjects have low fibre intake. Nutritional status were not correlated to picky eater behaviour with WAZ $(p=0.444), \operatorname{HAZ}(p=0.366)$ and WAZ ( $p=0.235)$.

Conclusions: There were correlation between picky eater behaviour and intake level. Subject with this behaviour needs to improve their intake level to prevent incident of underweight.

Keywords: picky eater, preschool children, nutritional status 
Korespondensi:

adheliaraputri@gmail.com

Departemen Gizi Kesehatan, Fakultas Kesehatan Masyarakat, Universitas Airlangga, Surabaya

\section{PENDAHULUAN}

Picky eater adalah perilaku memilih-milih makanan dengan terbatasnya jumlah pilihan makanan, tidak memiliki keinginan mencoba makanan baru, menghindari beberapa jenis makanan, dan memiliki pilihan makanan tertentu. ${ }^{1}$ Anak usia prasekolah mulai menunjukkan pilihan makanan yang disukai dan tidak disukai. Intensitas penolakan terhadap suatu makanan tergantung kepada temperamen anak. Orang tua sering kali salah dalam memberikan porsi makanan anak sehingga dengan mudah memberikan label picky eater pada anak. Terdapat beberapa faktor yang berpotensi menyebabkan risiko anak menjadi picky eater seperti anak dengan Atrial Septal Defect (ASD), anak dengan riwayat alergi, dan anak yang lahir secara prematur. ${ }^{2}$ Selain itu pada penelitian Horst, et al. $(2016)^{3}$ perilaku picky eater lebih banyak ditemukan pada anak berusia lebih tua, anak pertama, dan anak yang tidak pernah mendapatkan ASI.

Pada usia 0-48 bulan, rata-rata berat bayi bertambah $0,23 \mathrm{~kg}$ dan penambahan tinggi $1 \mathrm{~cm}$ setiap bulannya. Sedangkan pada usia prasekolah hanya mengalami penambahan berat badan sebanyak $2 \mathrm{~kg}$ dan penambahan tinggi $7 \mathrm{~cm}$ per tahunnya ${ }^{4}$, penurunan ini disebabkan oleh penurunan nafsu makan dan asupan. Kondisi ini termasuk normal pada usia prasekolah, namun jika kondisi kekurangan asupan secara jangka panjang, maka akan mengganggu pertumbuhan dan perkembangan anak. Adanya perilaku memilih makanan dan menghindari makanan oleh individu, kemungkinan anak dengan perilaku ini mengalami kekurangan atau kelebihan asupan gizi. ${ }^{4} 22,87 \%$ anak dengan perilaku picky eater memiliki nilai Z-score Berat Badan menurut Umur (BB/U), Tinggi Badan menurut Umur $(T B / U)$ dan Berat Badan menurut Tinggi Badan (BB/TB) lebih rendah dari anak yang tidak picky eater. ${ }^{5}$ Antoniou et al $(2016)^{6}$ menunjukkan bahwa hubungan antara picky eater dan berat badan ditemukan pada 2 kuartil ekstrem (atas dan bawah) dan tidak banyak yang di kuartil tengah. Pada penelitian Santos et al, (2011) ditemukan hubungan langsung antara kejadian obesitas dengan indikator picky eater yaitu pendekatan pada makanan. Penelitian menunjukkan bahwa anak pendek lebih banyak terjadi pada anak picky eater dibandingkan non picky eater ${ }^{5}$ Anak dengan status gizi buruk lebih rentan terkena penyakit akibat penurunan daya tahan tubuh, tidak optimalnya pertumbuhan dan perkembangan, hingga kematian. ${ }^{8}$ Penelitian ini dilakukan untuk menganalisis hubungan antara perilaku picky eater dengan tingkat kecukupan energi, karbohidrat, lemak, protein dan serat serta status gizi pada anak usia prasekolah di KB-TK AlHikmah Surabaya.

\section{METODE}

Jenis penelitian yang analitik observasional dengan desain studi cross-sectional. Sampel diambil melalui simple random sampling sebesar 45 responden dengan kriteriai inklusi: subyek berusia 41-59 bulan. Responden pada penelitian ini adalah orang yang paham dengan keseharian dari subyek. Data karakteristik responden diambil melalui pengisian kuesioner dan pengukuran antropometri dimana tinggi badan diukur menggunakan micotoise dengan ketelitian alat $0,1 \mathrm{~cm}$ dan berat badan subyek diukur dengan timbangan digital (OMRON Karada Scan HBF212) dengan ketelitian $0,1 \mathrm{~kg}$.

Pengukuran perilaku picky eater dilakukan dengan pengisian Child's Eating Behaviour Questionnaire dengan skor likert (skala 1-5). ${ }^{9}$ Kuesioner ini berisi 35 pertanyaan yang dibagi dalam dua kategori yaitu food approach dan food avoidance. Total skoring dari kuesioner dikategorikan picky eater jika jumlah total skor food avoidance lebih tinggi dari skor food approach. ${ }^{10}$ Pola konsumsi dan tingkat kecukupan zat gizi diukur dengan Semi Quantitative Food Frequency Questionnaire. Data tingkat kecukupan energi, karbohidrat, protein, lemak dan serat dibandingkan dengan angka kecukupan gizi (AKG) tahun 2013, defisit, jika $<90 \%$ AKG, Normal jika 90-119\% AKG, Lebih jika $\geq 120 \% .{ }^{11}$ Status gizi ditentukan dari data antropometri tinggi badan dan berat badan, kemudian diinterpretasikan dalam bentuk z-score menggunakan software komputer WHO Antro. Cut-off point indikator $\mathrm{BB} / \mathrm{U}$ gizi kurang $-3 \mathrm{SD} \mathrm{s} / \mathrm{d}<-2 \mathrm{SD}$, gizi baik $-2 \mathrm{SD} \mathrm{s} / \mathrm{d}$ $+2 S D$ dan gizi lebih $>+2 S D$. Indikator TB/U yaitu pendek -3SD $s / d<-2 S D$, normal -2SD $s / d+2 S D$ dan tinggi $>+2 S D$. Indikator $\mathrm{BB} / \mathrm{TB}$ yaitu sangat kurus $<-3 \mathrm{SD}$, kurus -3SD s/d <-2SD, normal -2SD s/d +2SD dan gemuk $>+2 S D$. Data pada penelitian ini dianalisis statistik dengan uji Spearman menggunakan software SPSS v25.0.

Penelitian ini telah mendapatkan keterangan layak etik dari komisi etik Fakultas Kesehatan Masyarakat Universitas Airlangga dengan nomor sertifikat: 168/EA/KEPK/2019.

\section{HASIL DAN PEMBAHASAN}

Penelitian ini melibatkan 45 subyek dengan $60 \%$ subyek berjenis kelamin perempuan. Usia rata-rata subyek adalah 53 bulan dengan minimal usia 41 bulan dan maksimal 59 bulan. Responden pada penelitian ini merupakan ibu dari subyek. Usia responden dalam penilitian ini dalam range minimal 25 tahun dan maksimal 47 tahun dengan jumlah responden yang berusia $25-35$ tahun sebesar $68,9 \%$. 
Sebagian besar responden $(91,1 \%)$ tamat PT namun masih ada responden yang menempuh pendidikan formal yaitu tamat SMP (2.2\%). 51,1\% responden bekerja dan selebihnya tidak bekerja. Berdasarkan tabel 2 dapat dilihat bahwa asupan energi rata-rata subyek adalah 1.791,52 kkal dengan asupan energi minimal 801,2 kkal dan maksimal 3.547,7. Asupan minimal karbohidrat subyek adalah 104,9 gram dengan rata-rata asupan karbohidrat 236,82 gram. Rata-rata asupan protein subyek adalah 65,75 gram dengan asupan protein minimal 25,4 gram. Asupan minimal lemak subyek adalah 16,9 gram gram dengan rata-rata asupan lemak 60,18 gram. Rata-rata asupan serat subyek adalah 7,48 gram dengan asupan serat minimal 2,4 gram.

Tabel 1 Karakteristik Responden

\begin{tabular}{lcc}
\hline \multicolumn{1}{c}{ Variabel } & $\mathbf{n}$ & $\mathbf{\%}$ \\
\hline $\begin{array}{l}\text { Usia Responden } \\
\text { 25-35 Tahun }\end{array}$ & 31 & 68,9 \\
$\begin{array}{l}\text { 36-47 Tahun } \\
\text { Tingkat }\end{array}$ & 14 & 31,1 \\
$\begin{array}{l}\text { Responden } \\
\text { Tamat SD }\end{array}$ & & \\
$\quad$ Tamat SMP & 0 & 0 \\
$\quad$ Tamat SMA & 1 & 2,2 \\
$\quad$ Tamat PT & 3 & 6,7 \\
Status Pekerjaan & 41 & 91,1 \\
$\quad$ Bekerja & & \\
$\quad$ Tidak bekerja & 23 & 51,1 \\
\hline
\end{tabular}

Tabel 3 menunjukkan bahwa terdapat 57,8\% subyek yang mengalami picky eater. Hasil penelitian ini ditemukan sebagian besar subyek memiliki perilaku picky eater. Hasil penelitian ini memiliki prevalensi picky eater yang tidak berbeda dari penelitian yang dilakukan oleh Hardianti ${ }^{5}$ di Kota Semarang, didapatkan 54,5\% anak usia 36-60 bulan yang memiliki perilaku picky eater dari total 63 sampel. Angka kejadian lebih tinggi pada penelitian ini bila dibandingkan dengan penelitian lain yang dilakukan Jakarta, ditemukan $25 \%$ dari 168 sampel yang memiliki perilaku picky eater. ${ }^{12}$ Namun masih lebih rendah jika dibandingkan dengan angka kejadian picky eater pada anak usia dua sampai lima tahun di Semarang pada tahun 2015 yaitu sebesar $60,3 \%$ anak mengalami picky eater. ${ }^{13}$ Perbedaan hasil ini dapat terjadi karena perbedaan karakteristik sampel seperti usia dan lingkungan pada setiap penelitian dan juga karena perbedaan metode pengategorian picky eater yang digunakan. Angka kejadian yang tinggi dikarenakan picky eater merupakan salah satu fase normal pada anak pra sekolah. Pada tabel 3, nilai rata-rata status gizi $\mathrm{BB} / \mathrm{TB}$, $\mathrm{BB} / \mathrm{U}$ dan $\mathrm{TB} / \mathrm{U}$ dengan $z$-score terkategori normal. Namun, data nilai minimal dan maksimal terlihat masih ada anak yang terkategori gizi kurang hingga gizi lebih.Pada distribusi status gizi Berat Badan menurut Umur subyek dalam tabel 3 didapatkan hasil 68,9\% subyek memiliki status gizi Berat Badan menurut Umur pada kategori normal, namun terdapat $22,2 \%$ subyek memiliki status gizi kurang. Untuk status gizi tinggi badan menurut umur, tidak terdapat subyek yang memiliki status tinggi badan sangat pendek. Sebanyak $82,2 \%$ subyek memiliki tinggi badan normal menurut umur dan
$13,3 \%$ subyek memiliki tinggi badan pendek. Pada status gizi berat badan menurut tinggi badan, 66,7\% subyek memiliki status gizi berdasarkan berat badan menurut tinggi badan normal dan $17,8 \%$ subyek memiliki status gizi kurus. Terlihat dalam tabel 4 pada tingkat kecukupan energi sebanyak $40 \%$ subyek memiliki tingkat kecukupan energi yang lebih dari nilai harian, namun masih terdapat $31,1 \%$ subyek yang mengonsumsi kurang dari $90 \%$ angka kecukupan gizi. Berdasarkan tabel 4 dapat disimpulkan bahwa 35,6\% subyek mengonsumsi karbohidrat lebih dari angka kecukupan karbohidrat perhari, namun, $40 \%$ subyek mengonsumsi kurang dari angka kecukupan karbohidrat. Untuk tingkat kecukupan protein, 82,2\% subyek mengonsumsi protein lebih dengan angka kecukupan protein dalam satu hari. 46,7\% subyek mengonsumsi lebih lemak banyak dari angka kecukupan harian. Seluruh subyek $(95,6 \%)$ kurang mengonsumsi serat.

Tabel 3. Distribusi Perilaku Picky eater dan Status Gizi Subyek

\begin{tabular}{lcc}
\hline \multicolumn{1}{c}{ Variabel } & $\mathbf{n}$ & $\%$ \\
\hline Kategori Picky eater & & \\
$\quad$ Picky eater & 26 & 57,8 \\
$\quad$ Tidak Picky eater & 19 & 42,2 \\
Indikator BB/U & & \\
$\quad$ Kurang & 10 & 22,2 \\
$\quad$ Normal & 31 & 68,9 \\
$\quad$ Lebih & 4 & 8,9 \\
Indikator TB/U & & \\
$\quad$ Pendek & 6 & 13,3 \\
$\quad$ Normal & 37 & 82,2 \\
$\quad$ Tinggi & 2 & 4,4 \\
Indikator BB/TB & & \\
Sangat kurus & 1 & 2,2 \\
$\quad$ Kurus & 8 & 17,8 \\
$\quad$ Normal & 30 & 66,7 \\
$\quad$ Gemuk & 6 & 13,3 \\
\hline
\end{tabular}

Rerata persentase asupan terlihat sudah memenuhi kebutuhan anak, tetapi masih ada subjek dengan persentase asupan kurang hingga lebih. Berbeda pada rerata asupan serat yang belum memenuhi kebutuhan harian anak. Rata-rata asupan lemak subyek berlebih karena lauk yang dikonsumsi subyek kebanyakan berupa gorengan. Beberapa tingkat kecukupan karbohidrat subyek masih kurang dari angka kecukupan perhari disebabkan subyek mengonsumsi sumber karbohidrat seperti nasi, dalam jumlah kecil dalam satu porsinya. Sumber karbohidrat lain seperti mie, kentang dan roti dikonsumsi tidak setiap hari dan dalam porsi kecil.

Tabel 4. Distribusi Tingkat Kecukupan Zat Gizi Subyek

\begin{tabular}{lcccccc}
\cline { 1 - 1 } \multicolumn{1}{c}{ Tingkat } & \multicolumn{2}{c}{ Defisit } & \multicolumn{2}{c}{ Normal } & \multicolumn{2}{c}{ Lebih } \\
Kecukupan & $\mathbf{n}$ & $\mathbf{\%}$ & $\mathbf{n}$ & $\mathbf{\%}$ & $\mathbf{n}$ & $\%$ \\
\hline Energi & 14 & 31,1 & 13 & 28,9 & 18 & 40 \\
Karbohidrat & 18 & 40 & 11 & 24,4 & 16 & 35,6 \\
Protein & 4 & 8,9 & 4 & 8,9 & 37 & 82,2 \\
Lemak & 13 & 28,9 & 11 & 24,4 & 21 & 46,7 \\
Serat & 43 & 95,6 & 0 & 0 & 2 & 4,4 \\
\hline
\end{tabular}


Tabel 2 Nilai Rerata, Standar Deviasi, Minimal dan Maksimal Data Usia, Status Gizi dan Asupan Subyek

\begin{tabular}{lccc}
\hline \multicolumn{1}{c}{ Variabel } & Rerata \pm SD & Minimal & Maximal \\
\hline Usia Subyek (bulan) & $53,02 \pm 6,061$ & 41 & 59 \\
Berat Badan (kg) & $16,67 \pm 4,64$ & 11,8 & 33,3 \\
Tinggi Badan (cm) & $103,9 \pm 7,1$ & 91,7 & 120 \\
Status Gizi Z-score & & & \\
$\quad$ BB/U & $-0,46 \pm 1,71$ & $-2,3$ & 4,53 \\
TB/U & $-0,594 \pm 1,23$ & $-2,352$ & 2,496 \\
BB/TB & $-0,272 \pm 2,16$ & $-4,391$ & 7,57 \\
Asupan zat gizi & & & \\
Energi (kkal) & $1.799,86 \pm 457,67$ & 927,1 & 2721,4 \\
Karbohidrat (g) & $227,44 \pm 61,55$ & 104 & 365,5 \\
$\quad$ Protein (g) & $60,95 \pm 19,15$ & 25,7 & 105,6 \\
$\quad$ Lemak (g) & $71,3 \pm 20,53$ & 31,9 & 111,8 \\
$\quad$ Serat (g) & $7,17 \pm 5,51$ & 2,3 & 30 \\
\hline
\end{tabular}

Belum tercukupinya kebutuhan harian disebabkan juga karena sebagian subyek (46\%) lebih menyukai snack daripada makanan pokok. Alasan yang diutarakan subyek terfokus pada rasa yang lebih enak dan packaging yang menarik sehingga anak lebih memilih snack. Selain itu $60 \%$ subyek mengatakan lebih menyukai makanan manis dan/atau berlemak daripada makanan sehat dengan alasan rasa yang lebih enak.

Asupan buah dan sayur sebagai sumber makanan tinggi vitamin dan mineral dapat mengakibatkan individu tidak memenuhi kebutuhan mikronutrien harian. Sebanyak 26,7\% subyek mengatakan bahwa anak menolak sayur dan buah dikarenakan tidak suka dengan teksturnya dan tidak mau mencoba. 16,7\% subyek tersebut masih mau mengonsumsi sayur namun menolak buah.

Tabel 5 menunjukkan bahwa subyek yang tingkat kecukupan energi defisit memiliki perilaku picky eater (53,8\%). Uji korelasi Spearman's Rho status perilaku picky eater dan tingkat kecukupan energi menghasilkan nilai p 0,000. Nilai tersebut menunjukkan terdapat hubungan antara perilaku picky eater dengan tingkat kecukupan energi. Nilai korelasi hubungan ini adalah $-0,717$ yang memiliki hubungan negatif yang cukup kuat, dimana semakin subyek tidak memiliki perilaku picky eater, maka semakin tinggi tingkat kecukupan energinya. Untuk tingkat kecukupan karbohidrat, sebanyak 65,4\% Untuk tingkat kecukupan lemak, dari 46,2 \% subyek dengan tingkat kecukupan lemak defisit memiliki perilaku picky eater. Hasil Uji korelasi Spearman's Rho menghasilkan nilai p 0,000 yang menunjukkan adanya hubungan antara perilaku picky eater dengan tingkat kecukupan lemak dengan nilai $r=$ 0,568 yang memiliki hubungan negatif, dimana ada kemungkinan semakin subyek tidak memiliki perilaku picky eater, maka semakin tinggi tingkat kecukupan lemaknya.

Pada tingkat kecukupan serat, didapatkan bahwa 96,2\% subyek dengan perilaku picky eater memiliki tingkat kecukupan serat terkategori defisit. Meskipun demikian, $94,7 \%$ subyek yang tidak berperilaku picky eater juga memiliki tingkat kecukupan serat yang kurang. Hasil uji statistik didapatkan nilai subyek yang tingkat kecukupan karbohidrat defisit memiliki perilaku picky eater. Uji korelasi Spearman's
Rho hubungan ini menghasilkan nilai p 0,000 yang menunjukkan adanya hubungan antara perilaku picky eater dengan tingkat kecukupan karbohidrat. Nilai korelasi hubungan ini adalah $r-0,566$ yang memiliki hubungan negatif yang cukup, dimana ada kemungkinan semakin subyek tidak memiliki perilaku picky eater, maka semakin tinggi tingkat kecukupan karbohidratnya. Pada tingkat kecukupan protein, sebanyak 15,4\% subyek yang tingkat kecukupan protein defisit memiliki perilaku picky eater dan $100 \%$ anak yang tidak memiliki perilaku picky eater mengonsumsi protein lebih dari angka kecukupan harian. Uji korelasi Spearman's Rho menghasilkan nilai p 0,007, menunjukkan terdapatnya hubungan antara perilaku picky eater dengan tingkat kecukupan protein dengan nilai korelasi -0,396, dimana ada kemungkinan semakin subyek tidak memiliki perilaku picky eater, maka semakin tinggi tingkat kecukupan proteinnya. $p=0,825$ sehingga tidak ditemukan hubungan antara perilaku picky eater dengan tingkat kecukupan serat.

Sebagian besar subyek yang tidak memiliki perilaku picky eater selalu menyukai makanan, selalu meminta makan dan menikmati makan serta selalu memiliki keinginan untuk makan. Sedangkan subyek dengan perilaku picky eater sebagian besar jarang meminta makan, tidak menikmati makanan yang beraneka ragam, memiliki nafsu makan yang rendah dan mudah merasa kenyang. Berdasarkan hasil kuesioner, dapat disimpulkan bahwa anak yang tidak memiliki perilaku picky eater menerima makanan lebih baik dan meminta makanan lebih banyak daripada anak dengan perilaku picky eater.

Berdasarkan hasil penelitian ini menunjukkan bahwa mayoritas subyek yang tidak memiliki perilaku picky eater memiliki tingkat kecukupan energi, protein, karbohidrat, dan lemak masuk dalam kategori lebih. Sedangkan subyek yang memiliki perilaku picky eater, memiliki kecenderungan tingkat kecukupan energi terkategori rendah dari angka kecukupan harian. Hal ini disebabkan karena subyek yang berperilaku picky eater mengonsumsi lebih sedikit jenis dan varian makanan sehingga tingkat kecukupan zat gizinya tidak terpenuhi. Penelitian ini didukung oleh penelitian lain dimana anak dengan perilaku picky eater ditemukan memiliki asupan energi lebih rendah dibanding anak yang tidak memiliki perilaku picky eater. ${ }^{14,15}$

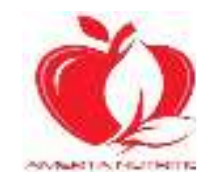

(C)2019. Putri dan Muniroh. Open access under CC BY - SA license. 
Selain itu ditemukan bahwa asupan protein lebih rendah pada anak dengan perilaku picky eater. ${ }^{3,16}$

Faktor yang dapat menyebabkan anak memiliki perilaku picky eater sehingga kekurangan asupan adalah tekstur dari makanan tersebut. ${ }^{3,17,18}$ Tekstur makanan yang lembek dan berlendir serta makanan dengan tekstur keras yang memerlukan mengunyah dapat membuat anak tidak tertarik. ${ }^{19}$ Sensitivitas yang lebih tinggi terhadap sentuhan dapat menyebabkan anak tidak menyukai rasa beberapa jenis makanan dalam mulut mereka, hal ini dapat menjadi alasan rendahnya asupan beberapa jenis makanan pada anak dengan perilaku picky eater. ${ }^{3}$

Tabel 5. Hubungan perilaku picky eater dengan tingkat kecukupan zat gizi subyek

\begin{tabular}{|c|c|c|c|c|c|}
\hline Tingkat Kecukupan Energi & $\begin{array}{c}\text { Defisit } \\
\mathrm{n}(\%)\end{array}$ & $\begin{array}{c}\text { Normal } \\
\mathrm{n}(\%)\end{array}$ & $\begin{array}{l}\text { Lebih } \\
\text { n(\%) }\end{array}$ & $\mathbf{p}$ & $\mathbf{r}$ \\
\hline Picky eater & $14(53,8)$ & $9(34,6)$ & $3(11,5)$ & 0,000 & $-0,717$ \\
\hline Tidak Picky eater & $0(0)$ & $4(21,1)$ & $15(78,9)$ & & \\
\hline Tingkat Kecukupan Karbohidrat & & & & $\mathbf{p}$ & $r$ \\
\hline Picky eater & $17(65,4)$ & $4(15,4)$ & $5(19,2)$ & 0,000 & $-0,566$ \\
\hline Tidak Picky eater & $1(5,3)$ & $7(36,8)$ & $11(57,9)$ & & \\
\hline Tingkat Kecukupan Protein & & & & $\mathbf{p}$ & $r$ \\
\hline Picky eater & $4(15,4)$ & $4(15,4)$ & $18(69,2)$ & 0,007 & $-0,396$ \\
\hline Tidak Picky eater & $0(0)$ & $0(0)$ & $19(100)$ & & \\
\hline Tingkat Kecukupan Lemak & Defisit & Normal & Lebih & $p$ & $r$ \\
\hline Picky eater & $12(46,2)$ & $8(30,8)$ & $6(23,1)$ & 0,000 & $-0,568$ \\
\hline Tidak Picky eater & $1(5,3)$ & $3(15,8)$ & $15(78,9)$ & & \\
\hline Tingkat Kecukupan Serat & Defisit & Normal & Lebih & $p$ & $r$ \\
\hline Picky eater & $25(96,2)$ & $0(0)$ & $1(3,8)$ & 0,825 & $-0,034$ \\
\hline Tidak Picky eater & $18(94,7)$ & $0(0)$ & $1(5,3)$ & & \\
\hline
\end{tabular}

Tabel 6. Hubungan Perilaku Picky eater Dengan Status Gizi Suby

\begin{tabular}{|c|c|c|c|c|c|}
\hline $\mathrm{BB} / \mathrm{U}$ & $\begin{array}{c}\text { Buruk } \\
\mathrm{n}(\%)\end{array}$ & $\begin{array}{c}\text { Kurang } \\
\mathrm{n}(\%)\end{array}$ & $\begin{array}{c}\text { Overweight } \\
\mathrm{n}(\%)\end{array}$ & $\begin{array}{c}\text { Obese } \\
\mathrm{n}(\%)\end{array}$ & p \\
\hline Picky eater & $0(0)$ & $6(23,1)$ & $19(73,1)$ & $1(3,8)$ & 0,444 \\
\hline Tidak Picky eater & $0(0)$ & $4(21,1)$ & $12(63,2)$ & $3(15,8)$ & \\
\hline TB/U & $\begin{array}{c}\text { Sangat pendek } \\
n(\%)\end{array}$ & $\begin{array}{c}\text { Pendek } \\
\mathrm{n}(\%)\end{array}$ & $\begin{array}{l}\text { Baik } \\
n(\%)\end{array}$ & $\begin{array}{l}\text { Tinggi } \\
\mathrm{n}(\%)\end{array}$ & $\mathbf{p}$ \\
\hline Picky eater & $0(0)$ & $3(11,5)$ & $21(80,8)$ & $2(7,7)$ & 0,366 \\
\hline Tidak Picky eater & $0(0)$ & $3(15,8)$ & $16(84,2)$ & $0(0)$ & \\
\hline BB/TB & $\begin{array}{c}\text { Sangat kurus } \\
n(\%)\end{array}$ & $\begin{array}{c}\text { Kurus } \\
\mathrm{n}(\%)\end{array}$ & $\begin{array}{l}\text { Baik } \\
\text { n(\%) }\end{array}$ & $\begin{array}{c}\text { Gemuk } \\
\mathrm{n}(\%)\end{array}$ & $p$ \\
\hline Picky eater & $1(3,8)$ & $5(19,2)$ & $18(69,2)$ & $2(7,7)$ & 0,235 \\
\hline Tidak Picky eater & $0(0)$ & $3(15,8)$ & $12(63,2)$ & $4(21,1)$ & \\
\hline
\end{tabular}

Tabel 6 menunjukkan bahwa sebanyak 63,2\% subyek dengan perilaku picky eater memiliki nilai z-score berdasarkan Berat Badan menurut Umur terkategorikan normal namun terdapat $21,1 \%$ subyek yang memiliki berperilaku picky eater. Uji korelasi Spearman's Rho menghasilkan nilai p 0,444, nilai tersebut menunjukkan tidak terdapat hubungan antara perilaku picky eater dengan status gizi berat badan menurut umur. $80,8 \%$ subyek dengan perilaku picky eater memiliki status gizi tinggi badan menurut umur normal namun terdapat $11,5 \%$ memiliki status gizi pendek. Uji korelasi Spearman's Rho status perilaku picky eater dan status gizi berdasarkan tinggi badan menurut umur menghasilkan nilai tersebut menunjukkan tidak adanya hubungan antara perilaku picky eater dengan status gizi berat badan menurut umur.

Berdasarkan tabel $6,80,8 \%$ subyek dengan perilaku picky tinggi badan menurut umur. Selain itu ditemukan bahwa subyek yang memiliki status gizi sangat kurus memiliki perilaku picky eater. Sebanyak $69,2 \%$ subyek yang memiliki perilaku picky eater berstatus gizi berat badan menurut tinggi badan normal. Uji korelasi Spearman's Rho status perilaku picky eater dan status gizi berdasarkan berat badan menurut tinggi badan menghasilkan nilai p 0,235 atau lebih dari nilai signifikansi 0,05. Nilai tersebut menunjukkan tidak adanya hubungan antara perilaku picky eater dengan status gizi berdasarkan berat badan menurut tinggi badan.

Subyek yang tidak berperilaku picky eater memiliki kemauan lebih untuk mengonsumsi makanan dalam jumlah dan frekuensi lebih besar. Selain itu variasi makanan yang dikonsumsi oleh subyek yang tidak berperilaku picky eater juga lebih beragam sehingga Pada dasarnya balita dengan perilaku pemilih makanan 
akan cenderung kekurangan asupan yang dapat menyebabkan penurunan berat badan dan berdampak pada status gizi anak tersebut. Namun dalam penelitian ini ditemukan bahwa tidak ada hubungan antara picky eater dengan status gizi responden. Picky eater cenderung menolak makan di suatu waktu, tetapi pada hari lain akan memakan makanan yang ditolaknya kemarin ${ }^{5}$. Perilaku tersebut dapat menyeimbangkan kebutuhan zat gizi walaupun tidak dikonsumsi setiap hari dan hal ini tetap memerlukan peranan orang tua. Hasil ini didukung oleh penelitian yang dilakukan oleh Kusuma $(2015)^{13}, 65,9 \%$ anak dengan perilaku picky eater berstatus gizi normal. Berdasarkan review sistematik yang dilakukan oleh Brown (2016) ${ }^{20}$, dari 41 studi yang direview, terdapat $41,46 \%$ studi yang menyatakan bahwa tidak ada hubungan antara picky eater atau food neophobia dengan status gizi. $41,1 \%$ studi diantara yang menyatakan tidak ada hubungan antara picky eater dengan status gizi menggunakan kelompok umur yang sama dengan penelitian ini yaitu 36-60 bulan.

Hal ini juga didukung oleh beberapa penelitian lain dimana tidak terdapat hubungan antara perilaku picky eater dengan status gizi BMI z-scores (Rohde, 2017). ${ }^{21}$ Horst $(2012)^{22}$ juga menemukan bahwa anak dengan perilaku picky eater tidak memiliki kecenderungan untuk mengalami berat badan kurang dibanding anak yang tidak memiliki perilaku picky eater. Berdasarkan Dobuis et $a^{23}$, anak dengan pilihan bawaan untuk lebih menyukai makanan manis dan berlemak memiliki kemungkinan besar berperilaku picky eater. Hubungan antara perilaku picky eater dengan status gizi masih tidak terlalu dipahami karena perilaku picky eater bisa saja berhubungan dengan berat badan lebih, dengan contoh asupan serat dari buah dan sayur yang rendah berhubungan dengan asupan lemak yang tinggi. ${ }^{22}$ Namun hal tersebut berbeda dengan yang ditemukan dalam penelitian ini, dimana tidak ada hubungan status gizi dengan picky eater. Terdapat kemungkinan dimana kejadian picky eater yang berkelanjutan memiliki efek jangka panjang terhadap status gizi yang tidak terlihat jelas hingga anak berusia lebih dari 9 tahun. ${ }^{6}$ Penelitian ini menunjukkan bahwa perilaku picky eater dapat mempengaruhi tingkat kecukupan zat gizi subyek namun tidak mempengaruhi status gizi subyek di KB-TK Al Hikmah Surabaya. Berdasarkan penelitian ini, hendaknya pihak sekolah menambahkan pengetahuan dasar terkait gizi dan kesehatan dalam kurikulum sehingga baik siswa, guru dan wali murid memahami pentingnya gizi dan kesehatan. Penelitian ini telah dilaksanakan sesuai dengan prosedur ilmiah, namun masih terdapat keterbatasan seperti faktor lain yang dapat mempengaruhi perilaku picky eater dan status gizi anak, selain itu keterbatasan penggunaakn kuesioner yang hanya menggambarkan perilaku dari pihak ibu.

\section{KESIMPULAN}

Pada hasil penelitian ini ditemukan bahwa terdapat hubungan yang signifikan antara perilaku picky eater dengan tingkat kecukupan energi, karbohidrat, protein dan lemak. Tidak ditemukan hubungan antara perilaku picky eater dengan tingkat kecukupan serat dikarenakan hampir seluruh subyek memiliki tingkat kecukupan serat yang kurang. Selain itu tidak ditemukan hubungan perilaku picky eater dengan status gizi berdasarkan $\mathrm{BB} / \mathrm{U}, \mathrm{TB} / \mathrm{U}$ dan BB/TB dikarenakan baik dengan perilaku picky eater atau tidak, status gizi subyek tergolong baik. Responden hendaknya memberikan makanan dengan varian lebih banyak sehingga dapat memenuhi kebutuhan zat gizi harian subyek.

\section{ACKNOWLEDGEMENT}

Peneliti mengucapkan terima kasih pada Yayasan Lembaga Pendidikan Islam Al-Hikmah Surabaya dan PGTK Al-Hikmah Surabaya serta wali murid PG-TK AlHikmah yang telah memberikan izin dan membantu peneliti melakukan penelitian di institusi tersebut.

\section{REFERENS}

1. Carruth, B. R., Ziegler, P. J., Gordon, A. \& Barr, S. I. Prevalence of picky eaters among infants and toddlers and their caregivers' decisions about offering a new food. J. Am. Diet. Assoc. 104, 5764 (2004).

2. Theresa, L. et al. Picky Eating and the Associated Nutritional Consequences. J. Food Nutr. Disord. 06, (2017).

3. van der Horst, K., Deming, D. M., Lesniauskas, R., Carr, B. T. \& Reidy, K. C. Picky eating: Associations with child eating characteristics and food intake. Appetite 103, 286-293 (2016).

4. Brown, J. Dietary Reference Intakes (DRIs): Recommended Intakes for Individuals, Vitamins Food and Nutrition Board, Institute of Medicine, National Academies. Fluoride (2011). doi:10.1111/j.1753-4887.2004.tb00011.x

5. Hardianti, R., Dieny, F. F. \& Wijayanti, H. S. Picky eating dan status gizi pada anak prasekolah. $J$. Gizi Indones. 6, 123 (2018).

6. Antoniou, E. E. et al. Picky eating and child weight status development: A longitudinal study. J. Hum. Nutr. Diet. 29, 298-307 (2016).

7. Santos, J. L. et al. Association between eating behavior scores and obesity in Chilean children. Nutr. J. 10, 108 (2011).

8. Diah Krisnansari. Nutrisi dan Gizi Buruk. Mandala Heal. 4, 60-68 (2010).

9. Wardle, J., Guthrie, C. A., Sanderson, S. \& Rapoport, L. Development of the children's eating behaviour questionnaire. J. Child Psychol. Psychiatry Allied Discip. 42, 963-970 (2001).

10. Tharner, A. et al. Toward an operative diagnosis of fussy/picky eating: A latent profile approach in a population-based cohort. Int. J. Behav. Nutr. Phys. Act. 11, 1-11 (2014).

11. Rosalind S. Gibson. Principles of Nutritional Assessment . Editor Rosalind S Gibson . Oxford University Press Inc . 2nd. 2005 (2005). doi:10.1201/9781420026221

12. Rahmawati, S. Faktor Predominan Perilaku Picky Eating Pada Siswa Kb / Tk Islam Al-Azhar 1 Jakarta Tahun 2013. Skripsi (2013).

13. Kusuma, H. S. \& Semarang, U. M. The 2 nd 
University Research Coloquium 2015 ISSN 24079189 STATUS GIZI BALITA BERBASIS STATUS PEMILIH MAKAN DI WILAYAH The 2 nd University Research Coloquium 2015 ISSN 24079189. 184-189 (2015).

14. Xue, Y. et al. Growth and development in Chinese pre-schoolers with picky eating behaviour: A cross-sectional study. PLoS One 10, 1-16 (2015).

15. Kwon, K. M., Shim, J. E., Kang, M. \& Paik, H. Y. Association between picky eating behaviors and nutritional status in early childhood:

Performance of a picky eating behavior questionnaire. Nutrients 9, (2017).

16. Taylor, C. M., Northstone, K., Wernimont, S. M. \& Emmett, P. M. Macro-and micronutrient intakes in picky eaters: A cause for concern?1-3. Am. J. Clin. Nutr. 104, 1647-1656 (2016).

17. Boquin, M. M., Moskowitz, H. R., Donovan, S. M. \& Lee, S. Y. Defining perceptions of picky eating obtained through focus groups and conjoint analysis. J. Sens. Stud. 29, 126-138 (2014).

18. Nederkoorn, C., Jansen, A. \& Havermans, R. C. Feel your food. The influence of tactile sensitivity on picky eating in children. Appetite 84, 7-10 (2015).
19. Russell, C. G. \& Worsley, A. Why do they like that? And can I do anything about it? The nature and correlates of parents' attributions and self-efficacy beliefs about preschool children's food preferences. Appetite 66, 34-43 (2013).

20. Brown, C. L., Schaaf, E. B. Vander, Cohen, G. M., Irby, M. B. \& Skelton, J. A. Association of Picky Eating and Food Neophobia with Weight: A Systematic Review. 12, (2016).

21. Rohde, J. F. et al. Relationship between pickiness and subsequent development in body mass index and diet intake in obesity prone normal weight preschool children. PLoS One 12, 1-9 (2017).

22. van der Horst, K. Overcoming picky eating. Eating enjoyment as a central aspect of children's eating behaviors. Appetite 58, 567574 (2012).

23. Dubois, L., Farmer, A. P., Girard, M. \& Peterson, K. Preschool children's eating behaviours are related to dietary adequacy and body weight. Eur. J. Clin. Nutr. 61, 846-855 (2007). 